\section{Intersections}

Canadian Journal of Music

Revue canadienne de musique
Intersections CANADIAN JOURAL OF MUSIC

\title{
Glenn Gould, Conductor: Critical Reception, Chronicle, and Commentary
}

\section{Timothy Maloney}

Volume 31, numéro 2, 2011

URI : https://id.erudit.org/iderudit/1013215ar

DOI : https://doi.org/10.7202/1013215ar

Aller au sommaire du numéro

\section{Éditeur(s)}

Canadian University Music Society / Société de musique des universités canadiennes

ISSN

1911-0146 (imprimé)

1918-512X (numérique)

Découvrir la revue

Citer cet article

Maloney, T. (2011). Glenn Gould, Conductor: Critical Reception, Chronicle, and Commentary. Intersections, 31(2), 79-98. https://doi.org/10.7202/1013215ar
Résumé de l'article

En 1982, environ deux mois avant sa mort, Glenn Gould a dirigé un orchestre de chambre de Toronto pour enregistrer Siegfried Idyll, de Richard Wagner. Les réactions à l'enregistrement, finalement sorti en 1990, varient énormément. Alors que Tim Page, lauréat du prix Pulitzer et spécialiste de Gould, le considère comme " une interprétation d'une tendresse émouvante et incomparable », Gunther Schuller, compositeur, chef d'orchestre et autre lauréat du prix Pulitzer, l'a qualifié d'« interprétation la plus inepte, la moins professionnelle et la plus aberrante jamais gravée sur vinyle d'une oeuvre majeure du répertoire classique ». À la lumière de cette divergence d'opinions extrême, l'auteur examine l'enregistrement, la direction d'orchestre de Gould et la réception des deux par la critique.
All Rights Reserved (C) Canadian University Music Society / Société de musique des universités canadiennes, 2012
Ce document est protégé par la loi sur le droit d'auteur. L'utilisation des services d'Érudit (y compris la reproduction) est assujettie à sa politique d'utilisation que vous pouvez consulter en ligne.

https://apropos.erudit.org/fr/usagers/politique-dutilisation/ 


\title{
GLENN GOULD, CONDUCTOR: CRITICAL RECEPTION, CHRONICLE, AND COMMENTARY
}

\author{
S. Timothy Maloney
}

The only commercial audio recording of Glenn Gould (1932-1982) conducting an ensemble showcased his interpretation of the chamber-orchestra version of Richard Wagner's Siegfried Idyll (WWV 103). A planned series of studio recordings with Gould conducting other orchestral repertoire never materialized, as he died about two months after the Wagner taping. The one track of his conducting was eventually added to Sony's reissue on compact disc ${ }^{1}$ of a 1973 Columbia LP of Gould performing his own piano transcriptions of orchestral music by Wagner, including the Siegfried Idyll. ${ }^{2}$

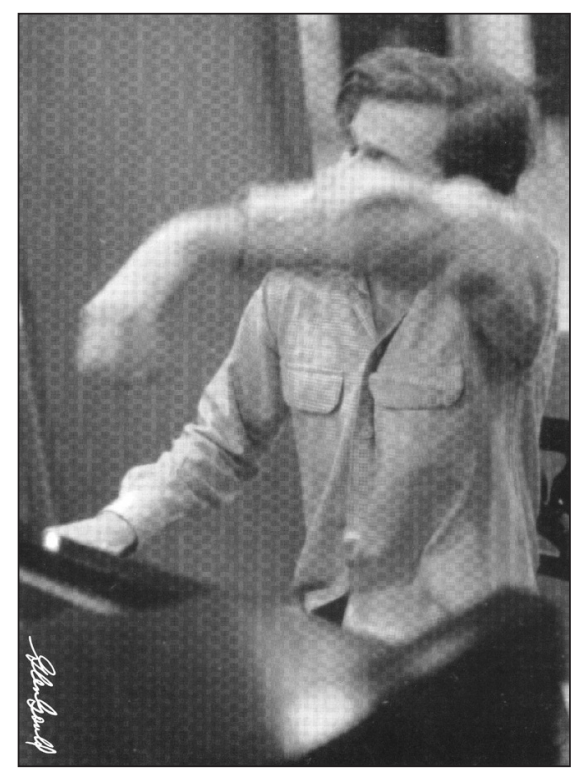

Figure 1. Gould in Columbia Records' 3oth Street Studio in New York, in June 1955, while recording his first Columbia album, Bach's Goldberg Variations. (Photograph Dan Weiner.) Glenn Gould magazine 8, no. 2 (Fall 2002): back cover. Unfortunately, no photography was permitted during the Siegfried Idyll recording sessions in 1982.

1 Glenn Gould Conducts and Plays Richard Wagner, Sony 1990.

2 Glenn Gould Plays Wagner, Columbia Records 1973. For further discussion about Gould's Wagner arrangements and interpretations, see Maloney 2007. 
Reactions to his conducted version of the work ranged from laudatory to highly critical. For example, the Gould biographer Peter Ostwald viewed it as "an elegant, slow-paced performance that emphasized the contrapuntal structure of Wagner's composition" (Ostwald 1997, 323); the Pulitzer Prize-winning critic and Gould scholar Tim Page considered it "a reading of melting and surpassing tenderness" (Page 2002, 71); and the musicologist and record reviewer Arnold Whittall saw it as "a labour of love" $(1991,1873)$. But for the critic Joseph Horowitz it was "a disturbing document" $(1995,134)$, while the Pulitzer Prizewinning composer-conductor Gunther Schuller declared it "probably the most inept, amateurish, wrong-headed rendition of a major classic ever put to vinyl" $(1997,6)$, and the record reviewer William Youngren described it variously as "grotesque ... execrable ... a nightmare" $(1991,388,390)$. In light of that extreme divergence of opinion, this article examines the recording, Gould's conducting, and the critical reception to both.

\section{Critical Reception}

Though Schuller gave no explanation as to why he found Gould's reading so "wrong-headed," his remarks, published in a monograph arguing strict adherence to the letter of the musical score, were part of a rant against "little-qualified" musicians pursuing "instant" conducting careers. Schuller evidently believed Sony's claim that the recording represented Gould's conducting debut, ${ }^{3}$ since he pronounced it "perhaps the saddest manifestation of this trend" $(1997,6)$.

Many Gould fans were aware that the pianist, even when playing alone, often gesticulated as if conducting the music when either hand was momentarily free (see figures 1 and 2), but it is not widely known that he had actually directed ensembles from the podium and (more often) the keyboard, and had been heard on radio and seen on television as a conductor as early as the $1950 \mathrm{~s}$ in Canada. In other words, despite Sony's hyperbole, Siegfried Idyll was not a true conducting debut, and the $\mathrm{CD}$ notes concede the point by alluding to "early attempts at conducting" (Folkman 1990, 4). Schuller's error undermines his argument against the "trend" in question, since Gould's disc manifested nothing of the kind, and one wonders how much that misperception may have coloured his opinion of the performance. ${ }^{4}$ (For the record, we will trace those "early attempts" in greater detail after further exploration of the reaction to the Siegfried Idyll recording.)

Other critics were more forthcoming than Schuller, and the major issue seems to have been Gould's "phenomenally slow" tempo (Horowitz 1995, 136). For instance, Youngren characterized the disc as "a 45-rpm record being played at 33" and suggested hearing it once and "never listen[ing] to it again" (1991,

3 The back cover of the Sony CD booklet reads, "Gould's Conducting Debut and Final Recording."

4 Schuller made a second error: this recording was never "put to vinyl," only to compact disc. And considering the many fine performances led by Ashkenazy, Carreras, Domingo, Galway, Kremer, Laredo, Perahia, Tuckwell, and others, one suspects Schuller has also overstated the case against this "trend." 


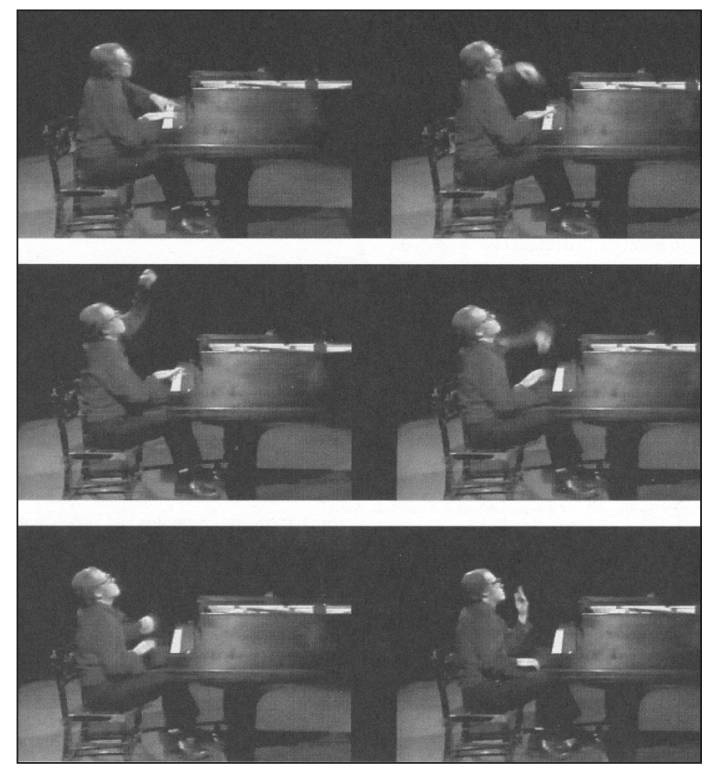

Figure 2. The final moments of Contrapunctus 14, in Bruno Monsaingeon's 1980 film An Art of the Fugue. Glenn Gould Magazine 8, no. 1 (Spring 2002): 34. A video of this performance, with all of Gould's conducting gestures, can be viewed at http:// www.youtube.com/watch? $=\mathrm{iDSAXtsDB} 5 \mathrm{k}$.

388). Perhaps the "excruciating ... agonizing" pace (ibid.) was also at the root of Schuller's "wrong-headed" comment.

Since Gould's tempo was so contentious, I compiled the timings of forty other recordings of the work (see table 1) to compare with Gould's; they range in duration from just over fifteen minutes to twenty-three and three-quarters, while Gould's ensemble reading lasted twenty-four and a half, about a minute longer than his own piano recording of the work (23:31) but under a minute longer than the most expansive non-Gould recording in the table. I was the first clarinetist of his Siegfried Idyll ensemble, and I can clearly recall his statement at the outset that our performance of it would be slower than any other on disc. He felt that "the piece has an indigenous languor which the 'ruhig bewegt' ... in the score does not adequately delineate" (Roberts and Guertin 1992, 202).

There have long been debates about the slower tempos favoured by German and Austrian conductors (e.g., Furtwängler, Karajan) versus the quicker speeds of Italian and French maestros (e.g., Toscanini, Monteux) in performances of standard orchestral repertoire. Wagner's own monograph, On Conducting, which (ironically) is devoted largely to a discussion of appropriate tempos, intriguingly suggests that "the pure adagio cannot be taken slow[ly] enough" (Wagner 1966, 314).5 Could the Siegfried Idyll not qualify as a "pure adagio?"

5 The original German is "In einem gewissen zarten Sinne kann man vom reinen Adagio sagen, dass es nicht langsam genug genommen werden kann” (Wagner 1914, 285). 
Table 1. Timings of Siegfried Idyll Recordings by Glenn Gould and 40 Other Conductors

\begin{tabular}{|c|c|c|c|c|}
\hline Conductor & Orchestra & Timing & Label \& Number & Year \\
\hline Steinberg & Pittsburgh Sym. Orch. & $15: 05$ & EMI CDM65208 & 1961 \\
\hline Paray & Detroit Sym. Orch. & 15:16 & Mercury SRW18054 & 1956 \\
\hline Ormandy & Philadelphia Orch. & $15: 28$ & Columbia MG30300 & 1971 \\
\hline Toscanini & New York Phil. Orch. & $16: 08$ & RCA 603172RG & 1936 \\
\hline Horenstein & Royal Phil. Orch. & $16: 15$ & Chesky CD-31 & 1962 \\
\hline Norrington & London Classical Players & $16: 19$ & EMI 5554792 & 1994 \\
\hline Rudolph & Columbia Sym. Orch. & $16: 21$ & Columbia ML5691 & 1961 \\
\hline Weingartner & London Phil. Orch. & $16: 36$ & Columbia X-139 & 1938 \\
\hline Furtwängler & Vienna Phil. Orch. & $16: 44$ & Testament SBT1141 & 1949 \\
\hline Blech & Berlin Phil. Orch. & $16: 59$ & Pearl GEMS0024 & 1923 \\
\hline Boulez & New York Phil. Orch. & $17: 04$ & Columbia M35131 & 1978 \\
\hline Stokowski & Symphony of the Air & $17: 08$ & Bridge 9074 & 1960 \\
\hline Cantelli & Philharmonia Orch. & $17: 13$ & Testament SBT1012 & 1951 \\
\hline Armenian & Canadian Chamber Ensemble & $17: 23$ & CBC 5073 & 1987 \\
\hline Jordan & Paris Kammerensemble & $17: 26$ & Image DVD 5037GC & 1995 \\
\hline Barenboim & Chicago Sym. Orch. & $17: 33$ & Teldec 3984242242 & 1999 \\
\hline Muck & Berlin Staatsoper Orch. & $17: 35$ & Electrola EH 561-562 & 1929 \\
\hline Klemperer & Philharmonia Orch. & $17: 41$ & Angel 3626B & 1962 \\
\hline Marriner & St.Martin's-in-the-Fields & $17: 45$ & Angel DS-37758 & 1980 \\
\hline Ashkenazy & English Cham. Orch. & 18:06 & London 410111 & 1981 \\
\hline Levine & Berlin Phil. Orch. & $18: 14$ & $\begin{array}{l}\text { Deutsche Grammophon } \\
435883\end{array}$ & 1991 \\
\hline Walter & Columbia Sym. Orch. & 18:15 & Odyssey Y30667 & 1971 \\
\hline Haitinck & Concertgebouw Orch. & $18: 18$ & Philips 412465 & 1974 \\
\hline Solti & Vienna Phil. Orch. & $18: 25$ & London CSA2216 & 1966 \\
\hline Leinsdorf & Boston Sym. Orch. & $18: 26$ & BSO CB 104 & 1965 \\
\hline Gerhardt & National Phil. Orch. & $18: 29$ & Chesky CD161 & 1997 \\
\hline Sawallisch & Vienna Sym. Orch. & $18: 41$ & Philips STLP900.503 & 1960 \\
\hline Knappertsbusch & Vienna Phil. Orch. & 18:52 & London LL1250 & 1955 \\
\hline Kubelik & Berlin Phil. Orch. & $18: 54$ & $\begin{array}{l}\text { Deutsche Grammophon } \\
439687-2\end{array}$ & 1958 \\
\hline Barbirolli & Hallé Orch. & 19:20 & BBC LK4076-2 & 1966 \\
\hline Sinopoli & New York Phil. Orch. & 19:22 & $\begin{array}{l}\text { Deutsche Grammophon } \\
419169\end{array}$ & 1985 \\
\hline Haenchen & Kammerorchester CPE Bach & $19: 30$ & Sony SK53109 & 1991 \\
\hline Karajan & Berlin Phil. Orch. & $19: 36$ & $\begin{array}{l}\text { Deutsche Grammophon } \\
\text { 449725-2 }\end{array}$ & 1977 \\
\hline Bernardi & National Arts Centre Orch. & $19: 40$ & CBC SM201 & 1972 \\
\hline Kempe & RAI Rome Sym. Orch. & $19: 40$ & Archipel ARPCD 0349 & 1955 \\
\hline
\end{tabular}


Table 1. (cont'd)

\begin{tabular}{lllll}
\hline \multicolumn{1}{c}{ Conductor } & \multicolumn{1}{c}{ Orchestra } & \multicolumn{1}{c}{ Timing } & \multicolumn{1}{c}{ Label \& Number } & Year \\
\hline Laredo & Scottish Chamber Orch. & $\mathbf{2 0 : 2 3}$ & MCA MCAD-25889 & 1989 \\
Tilson Thomas & $\begin{array}{l}\text { Lincoln Center Cham. Mus. } \\
\text { Soc. }\end{array}$ & $\mathbf{2 1 : 0 1}$ & OCLC81888171 & 1973 \\
Maazel & Berlin Phil. Orch. & $\mathbf{2 1 : 0 4}$ & RCA 74321-68717-2 & 1999 \\
Rögner & Berlin Radio Sym. Orch. & $\mathbf{2 2 : 2 1}$ & Ars Vivendi 2100195 & 1991 \\
Gould & solo piano & $\mathbf{2 3 : \mathbf { 3 1 }}$ & Columbia Masterworks & 1973 \\
& & & M32351 & 1993 \\
Celibidache & Munich Phil. Orch. & $\mathbf{2 3 : 4 5}$ & EMI 56524 & 1990 \\
Gould & [Toronto ensemble] & $\mathbf{2 4 : 2 8}$ & Sony SMK52650 & \\
\hline
\end{tabular}

* During a break in one of the recording sessions, the question of naming the ensemble came up, and some light-hearted banter ensued. Among the cleverest contributions were two by Gould mimicking the names of a pair of British ensembles: The Ashes of Toronto (in reference to The Fires of London) and The Academy of St. Lawrence in the Market (we were recording in the historic St. Lawrence Hall in Toronto, adjacent to the St. Lawrence Market). No "serious" names were suggested that evening, and the question was still unresolved when Gould died a couple of months later.

If it did, would Gould's "dreamy meditation"6 (Youngren 1991, 388) on it not be a more desirable approach, leaving the fifteen-minute gallops through it in the "nightmare" category? It is an idyll, 7 after all, that incorporates a German cradle song-a work Gould considered "as lyrical as a Chopin nocturne" (Gould 1973, 1).

Not to be overlooked in this discussion is the fact that Wagner included no metronome markings in any score after Tannhäuser. Since the composer specified no exact speed for Siegfried Idyll, giving only the verbal directions, Ruhig bewegt (which could be translated as "calmly moving" or "with calm motion"), ${ }^{8}$ Gould ignored no prescribed benchmark. And without a tradition or even a consensus among conductors (neither of which could be considered definitive, in any case) as to an appropriate speed for the work-the differential of over eight and a half minutes, or 57 per cent, between the quickest and slowest readings in table 1 clearly shows this-the question of tempo is ultimately irresolvable in this case as in so many others, hinging completely on current tastes and personal preferences.

The slowest readings in table 1 are generally of more recent vintage, while all but one of the quickest were recorded decades ago. Musical tastes change over time, and tempos wax and wane. Gould may simply have been "ahead of the curve" in his tempo choice for this work, as he was in so many other matters (e.g., championing Bach before the period-instrument movement of the late twentieth century; gambling on a strictly media-based career via discs, radio, television, and films following his "retirement" from the concert stage). With

6 This remark was made about Gould's piano performance of the work. Youngren apparently saw no inconsistency between his diametrically opposed reactions to Gould's interpretations of the work as pianist and as conductor, though their timings differ by less than a minute.

7 Definition: "a pastoral or romantic musical composition" (Webster).

8 Richard Wagner... 1995, 93. 
slower recordings of Siegfried Idyll currently ascendant, could the world be coming around to Glenn Gould's perspective on the pacing of this work? 9

Besides the tempo, critics took issue with other aspects of the recording. To Horowitz's ear, "Gould weights the lines to stress and enforce Wagner's polyphony. He discourages string vibrato to impose a cooling sheen. Some may find this Wagner style hypnotic and otherworldly. I find it Martian. Even the trills are microscopically scrutinized ... Not once do the players sound spontaneous or self-willed. No conductor on records ... has so evoked an ensemble of marionette instrumentalists" $(1995,135-36)$. Meanwhile, Youngren found the audio quality strange and suggested that the "players sound airlessly separated from one another, each sealed in his (or her) own isolation booth" (1991, 388).

As a participant in that recording, I can assert unequivocally that such notions as restricted vibrato, "cooling sheen," and so on are fanciful and inaccurate. First, vibrato is clearly audible in all instruments but the horns. I even used some on the clarinet. Next, regarding "airless" separation and isolation booths, we actually all sat relatively close together. There were no acoustical baffles or other sound-deadening furnishings anywhere in the room, which had plaster walls and a hardwood floor (in other words, its acoustics were quite live), and four of the six microphones were positioned to capture Gould's usual tight audio perspective, which is audible through much of the recording, though an overlay of artificial "reverb" can be heard towards the end. ${ }^{10}$ (The other two mics were farther away to capture room ambience.)

The unedited session tapes reveal faulty intonation and ragged entries and attacks, not all of which were ever corrected. Ensemble balance is another problem, and I agree with Horowitz that the audio pickup is uneven, with certain instruments dominating the foreground and the winds overwhelming the strings at the climax. But this was not by design. Gould seemed unaware of the problem. He had the chance to fix it at an extra session called to clean up particular spots five weeks after the original sessions ${ }^{11}$ but failed to do so. While it is possible that four close-in microphones were either too few for an ensemble of that size and makeup or were not ideally placed, the responsibility for imperfect balance in the final product must rest with the conductor.

The tape machines were stopped soon after each take ended, leaving minimal evidence of Gould's remarks to the ensemble, but my recollection is that he gave no instructions to individuals to correct imbalances. With respect to balance and other issues, Gunther Schuller lists seven kinds of ear needed by the "compleat" conductor: "(1) harmony; (2) pitch and intonation; (3) dynamics; (4) timbre; (5) rhythm and articulation; (6) balance and orchestrational aspects; and (7) line and continuity" (1997, 17-18). Judging by my experience with

9 A similar but smaller comparison found that tempos for performances of orchestral works by Debussy were generally slower after 1950 (Briscoe 1999a, 87-90).

10 Use of reverb was unheard of on earlier Gould recordings. According to Kevin Doyle, the audio engineer for this recording, it was used here to mask differences in horn tone or intonation when they spliced in material from the extra recording session that had been called to clean up a few spots (personal communication, 25 October 2007).

11 The original sessions took place 27-29 July 1982: 27 July was for strings only; the full ensemble met 28 and 29 July. The extra session was on 8 September. 
Gould, the second and sixth types were not among his strengths. Nor was an eighth I might propose for ensemble precision and togetherness: some "loose ends" of that kind on the finished Idyll recording may have sparked Schuller's "inept" and "amateurish" comments.

In addition to disregarding Gould's previous conducting experience, Schuller was clearly unaware that the decision to add the ensemble track of Siegfried Idyll to Sony's reissue of Gould's Wagner piano transcriptions was made by the pianist's estate, years after he died. The possibility cannot be ruled out that Gould himself might have chosen not to release it commercially, just as he abandoned a Beethoven concerto venture the same year (see below). Perhaps the Wagner project was part of a late apprenticeship Gould was prepared to pay for through studio rentals and musicians' and technicians' fees-the kind of training Schuller saw him as lacking.

An element Gould did focus on was articulation, including off-the-string accompaniment ${ }^{12}$ to the solo oboe in measures 91ff and 131ff. He also wanted extremely short staccatos for the repeated horn notes at bars 121-24 and 127-28. Although they sound odd at that tempo, Gould insisted they be absolutely secco, clearly a carry-over of his standard keyboard touch. Most intriguing from the perspective of the ensemble, though, was his tacet invitation to the musicians to manage their own nuances. For example, it was my decision to play the birdcall motive in measures 270-72 and 366-67 more lustig than piano, though both are indicated in the first clarinet part. (I did so by inserting an unwritten crescendo, accent, and diminuendo.) The flutist matched me when she played the same motive soon thereafter, and they remain that way on the CD.

Similarly, as the lead voice in the ensemble in bars 56-57, I stressed the first eighth-notes on the second beats (normally unstressed) for expressive purposes, and relaxed the tempo in measure 59, a bar before the poco ritardando in the score. Gould allowed me those liberties without comment. I also chose to begin the long clarinet trill in bars 356-57 slowly and increased the speed gradually until it resolved in bar 358 . Gould neither requested any of those interpretive details nor reacted to them. There are other examples throughout the recording that were all initiatives of the musicians themselves.

Many conductors, in striving to put their own stamp on performances, curb individual initiative by the musicians. By not micromanaging every detail, as some conductors are wont to do, Gould made us feel more like partners in the endeavour than sidemen to his maestro. Thus, Horowitz's comment about "marionette instrumentalists" is puzzling, since in reality it was quite the contrary. Despite such Gouldian touches as the slow tempo, measured string trills, and secco horn staccati, he was much more a collaborator than a dictator, though he clearly had a concept of the work he was trying to translate into sound. For me, that recording reflects a higher degree of personal initiative and artistry by the musicians than can be heard on several other recordings of

12 This involves lifting or bouncing the bow "off the string" between notes, as opposed to keeping the bow on the string through a sequence of notes. The latter technique sounds more legato, the former more staccato. 
Siegfried Idyll, and the record reviewer Carl Bauman seemed to recognize that when he wrote, "The Toronto players g[a]ve him their all" (1991, 146).

There was no consensus on this point, however: whereas Youngren dismissed the playing as "flat, pedestrian, undistinguished" (1991, 388), Whittall considered the music "well played" (1991, 1873); and while Whittall applauded particularly the "sense of repose at the end" (ibid.), for Bauman "the music end[ed] up flaccid rather than love-filled" $(1991,146)$. Chacun à son goût. For his part, Gould was extremely pleased: following one take, as the ensemble members observed normal recording-studio etiquette by maintaining complete silence for a few seconds after the work's final chord faded out, he quietly exclaimed, "Gorgeous! Magnificent! Heart-breaking!" The possibility of preserving those remarks on the master recording was reportedly discussed after he died, but ultimately they were not included on the Sony CD.

Let us add further perspective to this discussion by now reviewing Gould's "early attempts at conducting" and the critical reaction to them.

\section{Chronicle}

On 9 January 1954 at the Royal Conservatory of Music in Toronto, the twentyone-year-old Gould played Webern's Variations for Piano, op. 27, and led performances of Webern's Quartet for tenor saxophone, clarinet, violin, and piano, op. 22, and of Schoenberg's Das Buch der hängenden Gärten, op. 15, for voice and piano. The Toronto Globe and Mail of 11 January felt that "a great deal of credit belongs to Glenn Gould, pianist, who, without a score, was both conductor and accompanist in a difficult work [the Schoenberg] in which the only relationship between vocal and piano parts was that of mood" (Kraglund 1954). It should be noted that Gould's piano duties would likely have restricted him to intermittent conducting gestures at most.

Two and a half years later, on 9 July 1956 at the Stratford Shakespearean Festival (near Toronto), Gould again conducted from the keyboard. On the same program, Gould's own String Quartet received its second public performance. The next day's New York Times called Gould "the hero of the occasion," remarking that "besides appearing as a keyboard interpreter, a composer, [and] a program builder, Mr. Gould ... conducted from the piano in Schoenberg's Ode to Napoleon Bonaparte [op. 41, for voice, piano, and string quartet] and he wrote the first-class program notes" (Parmenter 1956). Gould's conducting was not specifically discussed and was likely limited again by the demands of the piano part.

On 20 February 1957, the Canadian Broadcasting Corporation (CBC) telecast a live concert of classical and popular music featuring Rosemary Clooney, Maureen Forrester, Glenn Gould, and an unidentified orchestra ${ }^{13}$ from Loewe's Uptown Theatre in Toronto. The television program was called "The Chrysler Festival.” After playing three movements of Bach's Partita no. 5 in G Major,

13 Likely the CBC Symphony Orchestra, which existed in Toronto 1952-64. 
BWV 829, ${ }^{14}$ Gould conducted the Urlicht movement of Mahler's Symphony no. 2 ("Resurrection") 15 with Forrester as the soloist. The Toronto Globe and Mail of 22 February called Gould's Bach "superb" but was less enamoured of his Mahler: "[Maureen Forrester's] vocal performance and interpretation were both of exceptional quality, despite the fact that Mr. Gould had been chosen as conductor. The qualification we feel to be justified, since Mr. Gould's directions could have been little guide for either instrumentalists or singer ... His movements were picturesque, but much too fluid to give indications of tempo, rhythm or accent" (Kraglund 1957).

This marked Gould's professional début as an orchestral conductor. A commercial videotape of the performance exists, ${ }^{16}$ apparently the only video document extant of Gould conducting an ensemble away from the keyboard. It bears out the critic's "qualification," showing that Forrester and the orchestra acquitted themselves admirably while Gould was stiff and awkward, his gestures unschooled and imprecise.

Two months later, on 16 April 1957, Gould wrote to Douglas Nixon, at CBC Vancouver, about conducting the CBC Vancouver Chamber Orchestra later that year: "I was delighted to hear ... that the date of September 5th would fit with your schedule for the CBC Orchestra in Vancouver ... Several ideas have occurred to me-among which would be a Bach or Mozart concerto (from the keyboard) - an all-Bach program or ... more general repertoire, possibly a Mozart or Schubert Symphony plus an overture."17 The actual program, broadcast coast-to-coast on CBC radio on 5 September 1957 and rebroadcast three weeks later on 26 September, included Mozart's first Symphony, K. 16 in E-flat Major and Schubert's Symphony no. 4 in C Minor, D. 417 ("Tragic"). ${ }^{18}$ Note the absence of a concerto, just the two symphonies, which Gould conducted from in front of the orchestra, the only complete program he ever conducted from the podium. It was performed in a Vancouver radio studio without an audience.

As was his custom at that time, Gould had an acetate disc recorded off the air by a Toronto recording engineer ${ }^{19}$ for his personal archives. That disc survives at Library and Archives Canada. ${ }^{20}$ Although it has suffered physical deterioration and the audio quality is poor by today's standards, Gould's trademark crispness and rhythmic energy are evident in both works. The orchestra's periodic détaché bowing and off-the-string articulations match Gould's well-known style of

14 This performance can be seen on Glenn Gould on Television: The Complete CBC Broadcasts 1954-1977, DVD 1.

15 This song is originally from the "Des Knaben Wunderhorn" collection.

16 See The Glenn Gould Collection, vol. 1; or Glenn Gould on Television: The Complete CBC Broadcasts 1954-1977, DVD 1. This video of Gould conducting Mahler can also be found at http://www .youtube.com/watch? $=$ =CWPKiuFmY4M.

17 Document 1979-20, 31, 3, 23, Glenn Gould Papers, Library and Archives Canada (LAC).

18 CBC Times, 1-7 Sept. 1957, 6; 22-28 Sept. 1957, 6.

19 Toronto audio engineers Les Smith and Stan Tulk (the father of Lorne Tulk, a CBC engineer who frequently worked with Gould later) arranged direct lines from the $\mathrm{CBC}$ to their studios and routinely offered this service to musicians until tape recording became widespread.

20 Audio document MUS109, Music Section, LAC. 
piano articulation. Also evident at moments in both works is a lack of ensemble precision, and deteriorating intonation in the finale of the Schubert. The out-oftune playing could be attributed to the perils of live-to-air broadcasts, standard in the 1950s, during which there was no possibility of doing retakes. Gould's inexperience could also have played a role, and the ragged entries and general scrappiness of the Schubert finale may well have been a direct result of too quick a tempo, lack of expertise on the podium, or both.

A year later, on 20 March 1958, Gould wrote to Vladimir Golschmann, conductor of the St. Louis Symphony and Gould's eventual recording partner on several discs, the first of which, Bach's Clavier Concerto no. 5 in F Minor (BWV 1056), they would record together two months later, in May 1958:

You have undoubtedly heard by now of my temporary retirement as a conductor which was due to a rather involved muscular reaction when I was doing some rehearsing up here. I became quite alarmed about the danger of conducting at any time close to piano performances ... This is one of my most fascinating symptoms and I would be happy to entertain you with it in great detail when I see you. For the present however, my retirement after a successful career of one concert [in Vancouver] which was at once my debut and my farewell appearance will, I am sure, be an irreparable loss in the music world. The one logical alternative is to retire from the piano and devote myself to conducting, which I am seriously considering. ${ }^{21}$

In light of all his subsequent piano performances, both in concert and on disc, it is clear that he was considering no such thing. He had told an interviewer late in 1957: "I had many plans for myself as a conductor but having done it twice this year, I've given them up. The concerts, in Toronto and Vancouver, were quite successful and I had a wonderful time. But after they were over, I couldn't go near a piano for two weeks. So I cancelled all my other conducting engagements. Don't ask me why; I don't even like to think about it."22

Gould's archives make reference to only one unfulfilled conducting commitment at that time, in St. Louis, so his reference to multiple engagements was, like his allusion to quitting the piano, not to be taken seriously. His shoulder and back muscles apparently tightened up during or after conducting, and Gould, a notorious hypochondriac, ${ }^{23}$ also complained of muscle pain. $\mathrm{He}$ attributed this discomfort to the incompatible muscle requirements for conducting and piano playing.

While there could be something to that theory, I would suggest that the level of tension in his shoulders and arms both when he played and conducted was counterproductive. By the mid- to late 1970s, Gould was experiencing major physical problems with his arms and hands, which caused him to cancel recording sessions and alter his choice of repertoire for television appearances on

\footnotetext{
21 Document 1979-20, 31, 5, 21, 1-2, Glenn Gould Papers, LAC.

22 Cited in Friedrich 1989, 274.

23 For example, see Dillon 2010, 212-37.
} 
the $\mathrm{CBC}$. He kept detailed diaries of these problems and his attempts to work through them, which have been described in some detail in several books. ${ }^{24}$

Returning to our chronicle of his conducting, on 29 August 1958, Gould wrote to Leonard Bernstein, addressing him as "Dear Leonardo," noting that he would be in Florence, Turin, and Rome in mid-November of that year when Bernstein was scheduled to conduct in Milan. "If it is at all feasible," Gould wrote, "I shall descend upon La Scala ... and take a few conducting lessons." ${ }^{25}$ This meeting apparently never took place. If it had, and if the lessons had occurred, Gould would surely have heard about avoiding tension in his arms and shoulders when conducting. Bernstein was among the loosest, most relaxed conductors I have ever worked with, in addition to being the most charismatic.

On 24 July 1960, Gould directed the Bach Clavier Concerto no. 1 in D Minor (BWV 1052) and the Brandenburg Concerto no. 5 in D Major (BWV 1050) from the keyboard at Stratford with the American violinist Oscar Shumsky, and the Canadian flutist Dirk Keetbaas, as the other soloists. The headline on the review in the following day's Toronto Star read, "Glenn Gould at Stratford 'Better than Ever."' The critic John Beckwith praised Gould for the "constructional aliveness" (1960), whatever that may mean, of both concerti but took him to task for using "a new piano of unusual qualities." Dubbed a "harpsi-piano" or "tack-hammer piano" by Gould, it had metal tacks applied to its hammers and dampers to emulate the sound of a harpsichord. As Beckwith pointed out, "If ... harpsichord-like effects are desired, the harpsichord, for heaven's sake, exists" (ibid.). ${ }^{26}$ There was no discussion of Gould's conducting per se in the review. Given the demands of the keyboard parts, his gestures were likely limited mainly to beginning and ending each movement.

The following summer, Gould participated in all-Bach concerts in Stratford and Vancouver. At the Vancouver International Festival on 9 August 1961, he led performances of Bach's Brandenburg Concerto no. 3 in G Major (BWV 1048), the Cantata no. 54, "Widerstehe doch der Sünde" (BWV 54), and the Clavier Concerto no. 7 in G Minor (BWV 1058). Francean Campbell wrote in the next day's Vancouver Province that "as conductor, soloist and speaker, Glenn Gould revealed himself anew" (1961), while Desmond Arthur in the Vancouver Sun, though extremely critical of the tack-hammer piano and Gould's spoken comments, called the string playing in the Brandenburg "clean, bright and altogether admirable" (1961).

The printed program for 13 August 1961 at the Stratford Festival lists Gould for the first time there as "pianist and conductor." From the keyboard, he directed the Brandenburg Concerto no. 3, the Clavier Concerto no. 7, and the Cantata no. 51, "Jauchzet Gott in allen Landen" (BWV 51). In the following

24 See Friedrich 1989, 244-47; Ostwald 1997, 298-303; and Bazzana 2004, 420-30.

25 Document 1979-20, 31, 6, 31, 1-2, Glenn Gould Papers, LAC.

26 Beckwith and Gould knew each other well, having both been piano students of Alberto Guerrero. Gould reportedly did not appreciate Beckwith's criticism about this and other matters, and their relations were strained thereafter (see Beckwith 1983, 74). Beckwith has subsequently written extensively about Gould. 
day's Toronto Star, John Beckwith again took Gould to task for his use of the "tack-piano" and professed boredom at the "unswerving metronomic beat of the fast movements" in the two concertos. However, he thought the cantata "had brilliance, a rhythmic élan and ease ... and many niceties of Bachian detail to delight the ear" (1961).

While the Stratford and Vancouver Bach concerts of 1960 and 1961 were not recorded, there is a CBC-TV studio recording of Gould leading the Fifth Brandenburg Concerto from the "harpsi-piano." It was taped in Toronto on 26 January 1962 and broadcast on 8 April of that year, with Oscar Shumsky, the American flutist Julius Baker, and a string ensemble comprising many of the same Toronto musicians who played annually at Stratford. Also taped at that session was the Bach Cantata no. 54, sung by the counter-tenor Russell Oberlin. ${ }^{27}$ Gould's ability to conduct was limited by his solo duties in the Brandenburg Concerto, though the less demanding keyboard part of the cantata allowed him some freedom to wave his left hand intermittently. The combination of first-class soloists, an experienced ensemble with dependable section leaders, and the steady pulse of Bach's music meant that there was little actual requirement for a conductor, except to begin and end the movements. (Let us recall that orchestral performances were routinely led from the harpsichord or first-violin desk until the late 170os, well after Bach's death.) Ultimately, the fact that both these performances were of the highest calibre likely depended less on how much or how well Gould conducted during the tapings and more on the details having been worked out in rehearsal.

Two years later, on 7 July 1963, Gould again participated in an all-Bach concert at Stratford, this time directing the Cantata no. 170, "Vergnügte Ruh, beliebte Seelenlust" (BWV 170), and the Concerto no. 6 in F Major for two flutes and keyboard (BWV 1057) from an actual harpsichord. (Perhaps the critics of the "tack-piano" had finally won him over.) As usual, the reviews made no mention of his conducting, which once again was likely limited by the demands of the keyboard parts. Later that year, he conducted the Canadian String Quartet and vocal soloists in a reading of his own composition, So You Want to Write a Fugue?, for the television series Festival, broadcast 15 October 1963 on CBC-TV. The videotape ${ }^{28}$ provides no evidence of his conducting, as the single camera focused almost exclusively on the singers.

In April 1964, Gould gave his last public concert, and his music-making thereafter took place only in broadcasting and recording studios. There appears to have been a complete break in his conducting activities from 1963 until two occasions in the 1970s, and then again until the early 1980 os.

On 21 December 1971, he wrote to the BBC producer Humphrey Burton, with whom he had collaborated in 1966 on four critically acclaimed television

27 See The Glenn Gould Collection, vol. 5; or Glenn Gould on Television: The Complete CBC Broadcasts 1954-1977, DVD 2, which includes the Brandenburg Concerto No. 5. Videos of this performance of Bach's Cantata No. 54 can also be seen at http://www.youtube.com/watch? $v=4$ SDpIyVhZKA, http:// www.youtube.com/watch?v=L1GrX $32 \mathrm{kpH}_{4}$, and http://www.youtube.com/watch?v=PdgRKstfFxM.

28 See The Glenn Gould Collection, vol. 4; or Glenn Gould on Television: The Complete CBC Broadcasts 1954-1977, DVD 3 
programs entitled "Conversations with Glenn Gould."29 In response to Burton's invitation, as Gould put it, "to take part in Volume 5 of the complete Burton-Gould conversations," Gould mentioned "having a bit of a Haydn fit at the moment ... I would like to do a major program ... devoted to his music. I would particularly like to finish off, or perhaps begin and end with something symphonic, directed from the harpsichord."30 Nothing ever came of that proposal, as Burton left the BBC about that time. ${ }^{31}$

In the same letter, Gould also discussed a current project: creating the music for a film based on Kurt Vonnegut's novel Slaughterhouse-Five. In early 1972, he conducted members of the string section of the New York Philharmonic from the harpsichord in recording excerpts of Bach's music, which Gould had arranged for the film. The spare, sensitive scoring of music for that film garnered widespread praise for the pianist. ${ }^{32}$

In 1974, Gould embarked upon two series for CBC Television featuring performances of, and discussion about, twentieth-century music. In a program in the Musicamera: Music in Our Time series, entitled "The Flight from Order: 1910-1920," broadcast on 5 February 1975, works of Prokofiev, Ravel, Schoenberg, Strauss, and Stravinsky were featured. Gould directed an instrumental ensemble from the piano in a performance of Schoenberg's Pierrot Lunaire, op. 21. Once again, due to the nature of the piano part, Gould was limited to gesturing intermittently with his left hand. The ensemble was made up of firstrank freelance and symphony musicians from Toronto, and the performance was extremely clean and well executed. 33

Early in 1982, Gould was asked to contribute the musical soundtrack for the film, The Wars, based on the novel of the same name by the Canadian writer Timothy Findley. Once again, he chose to arrange other composers' music rather than compose his own, a puzzling development in light of the great interest he professed in pursuing composition at the time he ceased concertizing in 1964. In any event, he chose some standard hymns and piano music by Brahms and Strauss as his raw material for this film, arranging bits of it for such diverse forces as solo harmonica and a duo of boy sopranos.

In his Gould biography, Otto Friedrich quotes the film's producer, Richard Nielsen, describing a recording session where Gould was conducting the choirboys in his arrangement of the theme from the Brahms Intermezzo, op. 117, no. 1: "It was a bizarre scene because Glenn was conducting these boys but he was crouched down in a pew where you couldn't see him. All you could see was a hand reaching out-looked like a totally disembodied hand. Utterly mesmerizing to watch" (1989, 269-79).

Gould had insisted many times over the years that he planned to give up the piano by age fifty to devote himself to other pursuits. As his fiftieth birthday

29 See Glenn Gould on Television: The Complete CBC Broadcasts 1954-1977, DVD 5 and DVD 6.

30 Document 1971-20, 32, 10, 7, 1-2, Glenn Gould Papers, LAC.

31 Personal communication, 14 February 1999.

32 For example, see Gilliatt 1972, 83.

33 See The Glenn Gould Collection, vol. 10; "Rhapsodic Interludes;" or Glenn Gould on Television: The Complete CBC Broadcasts 1954-1977, DVD 9. 
approached in the early $198 \mathrm{os}$, he began to refocus on conducting. As we have seen, his principal experience to that point as a "stand-up" conductor was limited to three works in two concerts in 1957, though he had frequently "directed" Bach and Schoenberg from the keyboard. When he was bringing his career as a pianist full circle in 1981 by re-recording Bach's Goldberg Variations (BWV 988), he was listing orchestral repertoire he wanted to conduct, including works by Bach, Beethoven, Brahms, Gluck, Handel, Haydn, Mendelssohn, Schoenberg, Sibelius, Strauss, Wagner, and Webern. He even drafted "Sample Programs" and "Dream Programs" 34 (see figure 3) and, besides purely orchestral repertoire, he entertained the notion of playing both principal roles in a piano concerto.

Probably as a result of his inability to find a conductor willing to record the piano and orchestra parts of a concerto separately, 35 the idea of acting as both conductor and soloist took root. He had performed with at least sixty-three conductors ${ }^{36}$ and must have felt scarred by some of the experiences, the most notorious of which occurred in 1962 when he performed the Brahms Piano Concerto no. 1 in D Minor, op. 15, with Leonard Bernstein and the New York Philharmonic. Their approaches to the work were so incompatible that Bernstein issued a disclaimer from the stage before the first performance. ${ }^{37}$

Such disagreements would be precluded if Gould acted in both capacities. So in April 1982 he hired the Hamilton (Ontario) Philharmonic Orchestra and John Klibonoff, then a Juilliard student, to record Beethoven's Piano Concerto No. 2 in B-flat Major, op. 19, under his direction. While Gould conducted the orchestra from the podium in the initial run-through, Klibonoff covered the solo part. Gould intended to set aside Klibonoff's tracks on the subsequent formal recording-session tapes and insert his own piano-playing after the fact. He was particularly keen to record that concerto because his previous recordings of the work were monaural, while his recordings of the four other Beethoven concerti were available in stereo. He wanted to complete a Beethoven concerto cycle recorded in stereo.

The audiotapes were left running for the entire session in Hamilton, probably the only audio evidence extant of Gould rehearsing an orchestra as its conductor. They reveal some of the same features evident in the 1957 Vancouver radio broadcast and the Siegfried Idyll recording. His approach to the first movement was straightforward but somewhat slower than many performances. The

34 Documents 1979-20, 22, 21, 20-24, Glenn Gould Papers, LAC.

35 Herbert von Karajan turned down the idea in 1976 but Neville Marriner reportedly agreed in 1982, though Gould died before they could carry out their plan (see Friedrich 1989, 278-81).

36 According to a handwritten list created by Gould: documents 1979-20, 21, 10 and 1979-20, 23, 94, 1, Glenn Gould Papers, LAC.

37 Sony Classical eventually produced a digitally remastered recording of that performance, as recorded during the live radio broadcast. It was released in Canada in 1998 as CD SK60675. Bernstein's controversial pre-concert remarks are included on the $\mathrm{CD}$. Though the conductor subsequently insisted no malice had been intended (see Bernstein 1983), and the pianist never took umbrage publicly, their close relationship ended and they never worked together again. Gould suffered criticism badly but preferred to avoid confrontations at all costs; instead, he quietly ended numerous friendships after perceived slights (e.g., with John Beckwith, Andrew Kazdin, Yehudi Menuhin, Peter Ostwald, and others). See Ostwald 1997, 297-98; Kazdin 1989, 51, 93, 122. See also note 26 above. 
$31 / 2(2011)$

93

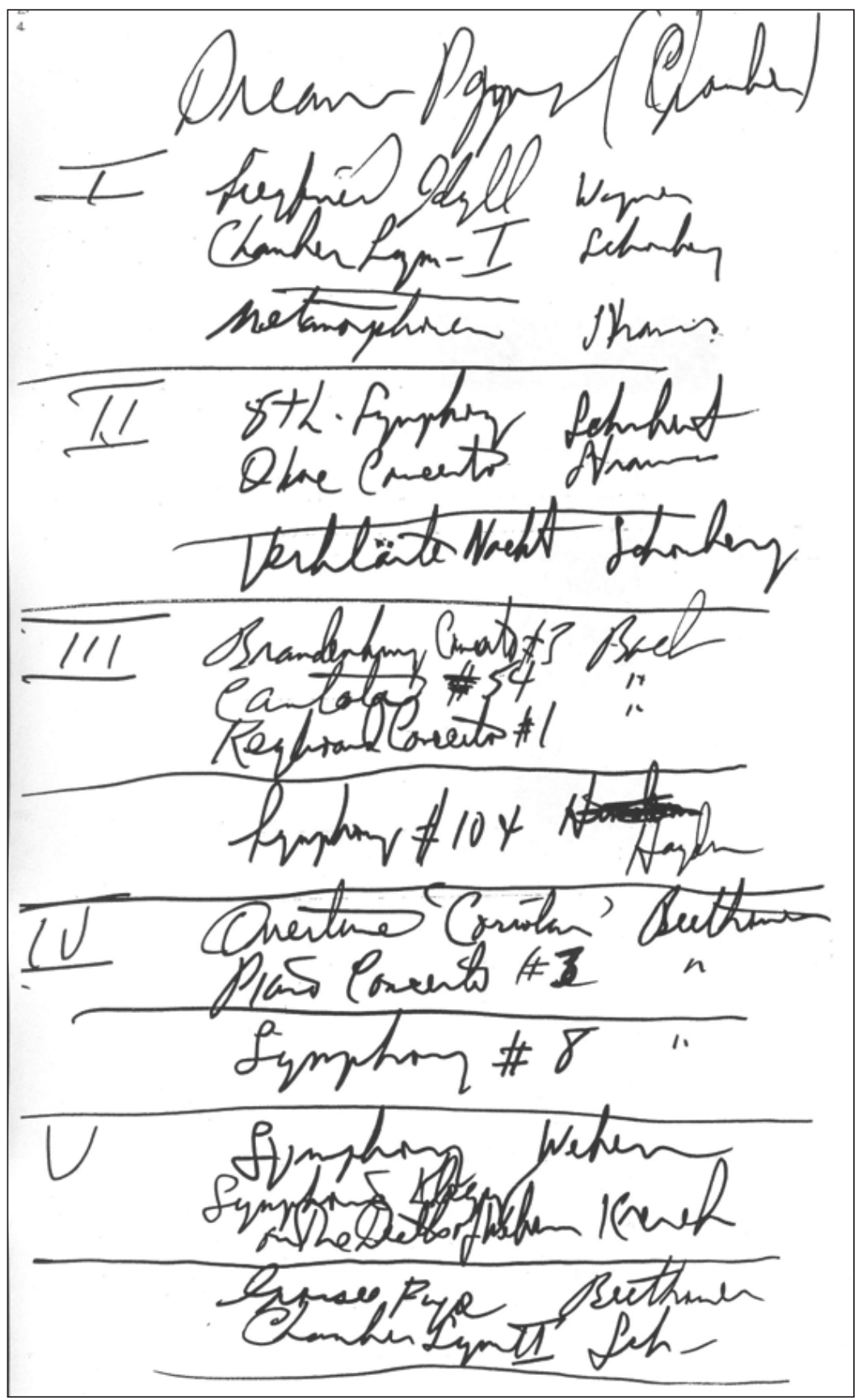

Figure 3. First page of a list of "Dream P[ro]g[ra]ms (Chamber)" drawn up by Glenn Gould. Document 1979-20, 22, 21, 20-24, Glenn Gould Papers, LAC [early 1980s]. 
second movement, however, was extremely slow, which caused problems for the young soloist in maintaining melodic flow, and the orchestra in coordinating entries and rhythms (e.g., the double-dotted rhythms in the winds in bars 4-6). While Gould was very particular about clear string articulations and offthe-string bowing at places in the first movement, he seemed less concerned with (or able to correct) ensemble untidiness, which was likely exacerbated by his "picturesque" conducting technique. The finale had barely begun when the time limit for the session was reached. Disappointed with the experience, ${ }^{38}$ Gould requested no overtime and arranged no further sessions with Klibonoff and the Hamilton orchestra.

As the first stage of an alternative project, he hired a group of Toronto Symphony and freelance musicians in July 1982 to record the original version of Wagner's Siegfried Idyll. This was the first piece on his list of "Dream Programs" (see figure 3) and the project was initially concluded in a matter of three evenings, though a fourth was scheduled later. ${ }^{39}$ What follow are some recollections and personal impressions of Gould the conductor based on my experience as a member of that ensemble.

\section{Commentary}

On the whole, Gould's conducting was of little help for certain aspects of the music. His gestures were generally expansive, as the Globe and Mail critic had pointed out in 1957, and sometimes (curiously) more in response to the music than actually leading it. Still more problematical was the lack of appreciable difference in his beat between legato and non-legato passages, and the total absence of an ictus much of the time. Without a rebound in the conductor's beat, instrumentalists cannot readily judge the quality of separation desired or, in extremis, the exact placement of certain rhythms or staccato notes. A baton might have helped but Gould did not use one, and, because he conducted lefthanded, his gestures were the mirror image of normal patterns, which required some mental adjustments by the Idyll musicians.

To compensate, we went into chamber-music mode: listening intently to each other for the beginnings and endings of phrases, doing our best to match volumes, using body language to synchronize entries and attacks when we could, and making eye contact when possible. However, since we were deployed in three rows, $4^{\circ}$ ultimately only a conductor could coordinate the entire ensemble.

I have witnessed the same teamwork among principal players of the Berlin Philharmonic while Karajan was in a trance-like state, with eyes closed and arms barely moving, so the need for musicians to take such initiative is not necessarily a result of incompetence on the podium. I have also worked with other conductors who did not excel in all of Schuller's "compleat" categories, yet most brought certain strengths to the podium. Musicians feel less stress

\footnotetext{
38 Personal communication from Ray Roberts, Gould's former associate, 6 December 1998.

39 See note 11.

40 Strings, woodwinds, and brass.
} 
playing for conductors whose technical fundamentals are sound, who lead consistently, who vary their gestures according to the dictates of the music, and who do everything possible to communicate clearly and effectively to their musicians at all times. Glenn Gould left something to be desired from most of these perspectives, and, on the basis of the video and audio evidence, the newspaper reviews, and my own experience playing under his direction, I must conclude that he was more successful "directing" Bach and Schoenberg from the keyboard than conducting other repertoire from the podium.

But while he may not have been as technically proficient as many conductors, he was an instinctive communicator who had a gift for identifying structural features in music that others did not always perceive, and for basing his interpretations on those foundations. Is this not another way of "respect[ing] rigorously the content of a score" (Schuller 1997, vii), possibly even a more profound way to "strive for the logic of the composer" (Briscoe 1999b, 184) than obsessing about foreground details or adhering to conventional wisdom and traditional tempi?

Gould's future as a conductor, had there been one, would undoubtedly have seen controversies and possibly some failures, but he would likely have engaged many listeners through his unusual premises. He claimed to approach each work "to do it differently, as it has never been done before" (Kostelanetz 1983, 134), and his recordings are, for the most part, deeply considered hypotheses and personal statements about the music. They represented all the thought and analysis he could bring to bear on each work, and they often broke new ground. He once insisted that "the performer has to have faith that he is doing ... the right thing, that he may be finding interpretive possibilities not wholly realized even by the composer" (Roberts 1999, 194). No less a conductor than Pierre Boulez shares that philosophy: "I am always looking for a solution that perhaps the composer did not think of ... [I]n the end you must find your own way" (Briscoe 1999b, 184). Glenn Gould's chamber-orchestra recording of Siegfried Idyll shows him trying to find his way as a conductor and interpreter of orchestral music. Had he subsequently addressed the technical deficiencies he exhibited while conducting Siegfried Idyll and corrected them in conducting other repertoire he planned to record, he might eventually have succeeded.

\section{Works Cited}

Arthur, Desmond. 1961. “Tacky, Talky: Gould Plays Games.” Vancouver Sun, 10 August.

Bauman, Carl. 1991. "Wagner: Siegfried Idyll; Wagner, arr. Gould: Meistersinger Overture; Dawn and Siegfried's Rhine Journey from Götterdämmerung; Siegfried Idyll." American Record Guide 54 (5): 146.

Bazzana, Kevin. 2004. Wondrous Strange: The Life and Art of Glenn Gould. Toronto: Oxford University Press.

Beckwith, John. 1960. "Glenn Gould at Stratford 'Better Than Ever.” Toronto Star, 25 July.

_.1961. "Bach Ends Festival Series." Toronto Star, 14 August. 
_. 1983. "Shattering a Few Myths." In Glenn Gould: By Himself and His Friends, ed. John McGreevy, 65-74. New York: Doubleday.

Bernstein, Leonard. 1983. "The Truth about a Legend." In Glenn Gould: By Himself and His Friends, ed. John McGreevy, 17-22. New York: Doubleday. Briscoe, James R. 1999a. "Debussy and Orchestral Performance." In Debussy in Performance, ed. James R. Briscoe, 67-90. New Haven: Yale University Press.

-1999b. "Debussy, Pelléas, and Orchestral Conducting: An Interview with Pierre Boulez.” In Debussy in Performance, ed. James R. Briscoe, 176-90. New Haven: Yale University Press.

Campbell, Francean. 1961. "All This and Bach Too: Gould's Piano Artistry a Bonus Event." Vancouver Province, 10 August.

Dillon, Brian. 2010. "Glenn Gould: Not of the World." In The Hypochondriacs: Nine Tormented Lives, 212-37. New York: Faber and Faber.

Folkman, Benjamin. 1990. Liner notes to Glenn Gould Conducts and Plays Wagner. Compact disc SMK46279. Austria: Sony Classical GmbH.

Friedrich, Otto. 1989. Glenn Gould: A Life and Variations. Toronto: Lester \& Orpen Denys.

Gilliatt, Penelope. 1972. “The Current Cinema: Slaughterhouse." New Yorker, 1 April.

The Glenn Gould Collection. Vol. 1, Prologue. 1992. Videocassette SHV 48402. Austria: Sony Music Entertainment.

__. Vol. 4, So You Want to Write a Fugue? 1992. Videocassette SHV48406. Austria: Sony Music Entertainment.

- Vol. 5, The Conductor. 1992. Videocassette SHV48408. Austria: Sony Music Entertainment.

. Vol. 10, Rhapsodic Interludes. 1992. Videocassette SHV48415. Austria: Sony Music Entertainment.

—_. Vol. 15, An Art of the Fugue. 1992. Videocassette SHV 48426. Austria: Sony Music Entertainment.

Glenn Gould Conducts and Plays Richard Wagner. 1990. Compact disc SMK52650. Austria: Sony Classical GmbH.

Glenn Gould on Television: The Complete CBC Broadcasts 1954-1977. DVD 1, Early TV Performances and Program Excerpts 1954-1974: The Subject Is Beethoven. 2011. Digital Video Disc 88697952109-01. Austria: Sony Music Entertainment.

-DVD 2, Music in the U.S.S.R.; Glenn Gould on Bach. 2011. Digital Video Disc 88697952109-02. Austria: Sony Music Entertainment. -.DVD 3, Richard Strauss: A Personal View; The Anatomy of the Fugue. 2011. Digital Video Disc 88697952109-03. Austria: Sony Music Entertainment. .DVD 5, Conversations with Glenn Gould: Humphrey Burton Interviews; Bach and Beethoven. 2011. Digital Video Disc 88697952109-05. Austria: Sony Music Entertainment.

.DVD 6, Conversations with Glenn Gould: Humphrey Burton Interviews; Schoenberg and R. Strauss. 2011. Digital Video Disc 88697952109-06. Austria: Sony Music Entertainment. 
- DVD 9, Musicamera: Music in Our Time; The Age of Ecstasy 190o-1910; The Flight from Order 1910-1920. 2011. Digital Video Disc 88697952109-09. Austria: Sony Music Entertainment.

Glenn Gould Plays Wagner. 1973. Long-playing disc. Columbia Masterworks M32351. New York: Columbia Records.

Gould, Glenn. 1973. "Interview with Ken Haslam.” Broadcast on CBC Radio February 1973. Transcription inserted in slipcase of Glenn Gould Plays Wagner. Long-playing disc M32351. New York: Columbia Masterworks.

Horowitz, Joseph. 1995. "Precision Engineering: Glenn Gould and the Phonograph." In The Post-Classical Predicament: Essays on Music and Society, 134-38. Boston: Northeastern University Press.

Kazdin, Andrew. 1989. Glenn Gould at Work: Creative Lying. New York: E. P. Dutton.

Kostelanetz, Richard. 1983. "Glenn Gould: Bach in the Electronic Age." In Glenn Gould: By Himself and His Friends, ed. John McGreevy, 125-41. New York: Doubleday.

Kraglund, John. 1954. "Music in Toronto: Modern Music Concert Fails to Fill Conservatory Hall." Toronto Globe and Mail, 11 January.

- 1957. "Music in Toronto." Toronto Globe and Mail, 22 February.

Maloney, Timothy. 2007. "Glenn Gould and Richard Wagner." In Richard Wagner for the New Millennium: Essays in Music and Culture, ed. Mathew Bribitzer-Stull, Alex Lubet, and Gottfried Wagner, 43-69. New York: Palgrave MacMillan.

Ostwald, Peter. 1997. Glenn Gould: The Ecstasy and Tragedy of Genius. New York: W. W. Norton.

Page, Tim. 2002. "Glenn Gould in Retrospect." In Tim Page on Music: Views and Reviews, 68-73. Portland, OR: Amadeus.

Parmenter, Ross. 1956. "Glenn Gould Is Piano Soloist, Conductor and Annotator of a Program in Canada." New York Times, 10 July.

Richard Wagner. Sämtliche Werke. Band 18.III: Orchesterwerke. Siegfried Idyll, WWV 103. 1995, ed. Peter Jost, 93-118. Mainz: Schott Musik International. Roberts, John P. L., ed. 1999. The Art of Glenn Gould: Reflections of a Musical Genius. Toronto: Malcolm Lester Books.

Roberts, John P. L., and Ghyslaine Guertin, eds. 1992. Glenn Gould: Selected Letters. Toronto: Oxford University Press.

Schuller, Gunther. 1997. The Compleat Conductor. New York: Oxford University Press.

Wagner, Richard. 1914. "Über das Dirigieren." In Gesammelte Schriften und Dichtungen, Achter Band, ed. Wolfgang Golther, 261-337. Berlin: Deutsches Verlagshaus Bong.

—. 1966. "About Conducting." In Richard Wagner's Prose Works. Vol. 4, Art and Politics, trans. William Ashton Ellis, 289-364. New York: Broude Brothers.

Webster's Third New International Dictionary of the English Language, Unabridged, s.v., "idyll." 
Whittall, Arnold. 1991. "Wagner. Siegfried Idyll. Piano Transcriptions (Gould)." Gramophone: Review of New Classical Recordings 68 (815): 1873.

Youngren, William. 1991. "Wagner. Siegfried Idyll. Die Meistersinger. Prelude. Götterdämmerung: Dawn and Siegfried's Rhine Journey. Siegfried Idyll." Fanfare: The Magazine for Serious Record Collectors 15 (1): 388-90.

\begin{abstract}
In 1982, about two months before he died, Glenn Gould conducted a Toronto chamber orchestra to record Richard Wagner's Siegfried Idyll. Reactions to the recording, eventually released in 1990, varied dramatically: while the Pulitzer Prize-winning critic and Gould scholar Tim Page considered it "a reading of melting and surpassing tenderness," the composer-conductor Gunther Schuller, also a Pulitzer Prize winner, declared it "the most inept, amateurish, wrong-headed rendition of a major classic ever put to vinyl." In light of that extreme divergence of opinion, this article examines the recording, Gould's conducting, and the critical reception to both.
\end{abstract}

\title{
RÉSUMÉ
}

En 1982, environ deux mois avant sa mort, Glenn Gould a dirigé un orchestre de chambre de Toronto pour enregistrer Siegfried Idyll, de Richard Wagner. Les réactions à l'enregistrement, finalement sorti en 1990, varient énormément. Alors que Tim Page, lauréat du prix Pulitzer et spécialiste de Gould, le considère comme "une interprétation d'une tendresse émouvante et incomparable», Gunther Schuller, compositeur, chef d'orchestre et autre lauréat du prix Pulitzer, l'a qualifié d'«interprétation la plus inepte, la moins professionnelle et la plus aberrante jamais gravée sur vinyle d'une œuvre majeure du répertoire classique». À la lumière de cette divergence d'opinions extrême, l'auteur examine l'enregistrement, la direction d'orchestre de Gould et la réception des deux par la critique. 